\title{
Synthesis of Antiseptic Soap from Blends of Wood Tar and Some Selected Vegetable Oils
}

\author{
Abdu Zubairu, Abdullahi S. B. Gimba, and Mohammed B. Korode
}

\begin{abstract}
Antiseptic soap is a cleansing product to which active ingredient have been added to kill bacteria or germs. Usually, the price associated with conventional antiseptic soap is prohibitive, thus the need for cheap alternative sources of antiseptic soap could not be overemphasized. Traditionally, wood tar inherits antiseptic properties from the parent tree, it therefore provides an easily accessible and affordable recipe for antiseptic soap manufacture. In this paper, we elucidate the use of wood tar extracted from selected local trees (cassia, eucalyptus, and neem) as feedstock to synthesize antibacterial soap, by blending separately with vegetable oil. Two common vegetable oils (castor and peanut oils) were used in this work. The wood tar extracted by destructive distillation of the wood was characterized using gas chromatography and mass spectrometry techniques. The analysis indicates that wood tar from the selected trees contain antiseptic components like creosol. The optimum blend ratios of wood tar to vegetable oil suitable for saponification in terms of soap yield was also investigated. Similarly, the soap formulation from optimum blend of wood tar and vegetable oil was characterized to determine $\mathrm{pH}$, foam ability, cleansing power and the microbial activity of the soap. The antimicrobial sensitivity results indicate that the soap has significant inhibitory property on $E$. coli bacteria. More also, for the selected vegetable oils considered, peanut oil blend was found to give higher yield of soap compared to castor oil blend.
\end{abstract}

Index Terms - Antiseptic soap, Castor oil, Foamability, Destructive distillation, Peanut oil, Wood tar.

\section{INTRODUCTION}

Soaps are cleansing agents obtained by treating vegetable oils or animal fats with a strong alkaline solution. Fats - the solid esters of fatty acids and glycerin, and oils - the liquid glycerol esters of fatty acids at room temperature, both primarily composed of triglycerides. The triglycerides composed of three molecules of fatty acids attach to a backbone of single molecule of glycerol [1]. Soap is often defined as a chemical compound or mixture of chemical compounds resulting from the reaction of fatty acids or fatty glycerides with a metal radical or organic base [2]. Soap molecule composed of a long hydrocarbon chain (twelve or more carbon atoms) with carboxylic acid group that is ionically bonded to a metal - usually sodium or potassium radical, at one end. The length of hydrocarbon chain and the number of double bonds in the carboxylic acid portion of the fat or oil determine the properties of the resulting soap [3].

One other hand, antiseptic soap or antibacterial soap is any

Published on January 8, 2021.

A. Zubairu, Dept. of Chemical Eng'g, University of Maiduguri, Nigeria. (e-mail: azubairu@unimaid.edu.ng)

A.S. B. Gimba, Dept. of Petr and Gas Eng'g, Nile University, Nigeria

(e-mail: dr.abduallahi.gimba ${ }^{@}$ gmail.com) cleaning product to which active antimicrobial ingredients have been added. These additives kill bacteria and microbes but are no more effective at deactivating viruses than any other kind of soap or detergent, and they also kill nonpathogenic bacteria. Due to high prices associated with conventional antiseptic soaps, the need for alternative sources of antiseptic soap could not be over emphasized.

There are various vegetable oils that are used in the production of soap such as jatropha oil, palm oil, castor oil, peanut oil, neem oil, shear butter oil, etc. In this work castor oil and peanut oil were used due to availability and favourable cost.

Castor oil is an inexpensive and environmentally friendly oil. The oil is viscous, yellow, non-volatile and non-drying, often used as a purgative. Castor in soaps contributes to fluffy, stable lather, conditioning, moisturizing, quicker trace, softer soap. It is often used to super fat soaps. Like olive oil and jojoba oil, castor oil acts as humectants by attracting and retaining moisture to the skin [3].

Peanut oil, also known as groundnut oil or arachis oil, is a mild-tasting vegetable oil derived from peanuts. The oil is available with a strong peanut flavor and aroma, analogous to sesame oil [4] Peanut oil, as with other vegetable oils, can be used to make soap by the process of saponification. The oil is safe for use as a massage oil. The stable lather produced by peanut oil is superb and is also good for the skin due to its conditioning properties.

\section{WOOD TAR}

\section{A. Background}

Wood tar is a viscous liquid obtained as one of the products of the carbonization, or destructive distillation, of wood. Wood tars are classified based on their origin or sources, and two types are commonly identified: hardwood tars, derived from such woods as oak and beech; and resinous tars, derived from pine wood, particularly from resinous stumps and roots. Crude wood tar may be used as fuel or for preserving rope and wood and for caulking. The tar may be fractionated to yield creosote, oils, and pitch. In pharmacy, wood tar is used as a component of some ointments and antiseptics. Distillates of pine-wood tar, particularly the creosote fraction, are used in metallurgy in the froth flotation processes [5].

M. B. Korode, Dept. of Chemical Eng'g, University of Maiduguri, Nigeria. (e-mail: mahbuls ${ }^{\circledR}$ yahoo.com). 


\section{B. Sources of Wood Tar}

Wood tar is commonly extracted from different source trees. The yield and characteristics of the wood tar depend on the source tree. In this work, three plants were selected namely: eucalyptus tree, cassia tree and neem tree to tap wood tar.

Eucalyptus is a diverse genus of flowering trees and shrubs (including a distinct group with a multiple-stem mallee growth habit) in the myrtle family, myrtaceae. Members of the genus dominate the tree flora of Australia, also located in southern Asia and Africa. Eucalyptus are grown as exotic plantation species in tropical and subtropical regions of Nigeria and in more temperate regions because of their capacity for fast growth and tolerance of harsh environment involving many effective adaptations: indeterminate growth, coppicing, lignotubers, drought, fire, insect resistance and tolerance of soil acidity and low fertility [6]. There are more than 700 species of eucalyptus and are mostly native of Australia [7].

Cassia fistula, known as the golden shower tree, is a flowering plant in the family Fabaceae. Cassia sieberiana, similar specie also is a tree in the Fabaceae family native to Africa. It ranges from 10-20 meters in height and has very bright yellow flowers. It is used for multiple medical purposes in Africa (found in multiple parts of Africa including the southern part of the Sahel, Nigeria, Senegal, Sudan, and Uganda). Cassia fistula is widely grown as an ornamental plant in tropical and subtropical areas. It blooms in late spring, flowering is profuse, with trees being covered with yellow flowers, many times with almost no leaf being seen. In Ayurvedic medicine, the golden shower tree is known as aragvadha, meaning "disease killer". The fruit pulp is considered a purgative [8] and self-medication. Though it has been used in herbalism in the olden days, little research has been conducted in modern times.

Azadirachta indica, also known as neem, is a tree in the mahogany family meliaceae. In Nigeria, neem tree popularly called dogonyaro in the north has been known in Nigeria for centuries, having been introduced into the country by Cameroonian traders through Borno State. The Neem tree is widely grown in the North-eastern sub-region, perhaps, due to the region's conducive climate which is strategically located within the Sahel Savanna belt of West Africa [9]. Neem is a fast-growing tree that can reach a height of 15-20 meters. It is evergreen, but in severe drought it may shed most or nearly all of its leaves. Neem products are believed to be antihelmenthic, antifungal, antidiabetic, antibacterial, antiviral, contraceptive, and sedative [10]. Neem leaves have also been used to treat skin diseases like eczema, psoriasis, etc.

\section{METHODOLOGY}

\section{A. Wood Tar Extraction: Open Fire Method}

Neem, eucalyptus, and cassia branches were cut, and sun dried for 48 hours to reduce the moisture content to about $50 \%$ from the initial moisture levels. Three separate batches of $1 \mathrm{~kg}, 2 \mathrm{~kg}$ and $3 \mathrm{~kg}$ from each tree were weighed and transferred into separate sealed metal containers. A fabricated metal kiln was used for the extraction of the wood tar. The sealed metal container was buried halfway into the ground to provide an insulation at the bottom of the metal container, (the insulation provides for a lower temperature which allows for the condensation of the tar substance), a collection can was placed beneath the metal container which also served as the wood tar storage. The metal container has a small hole at the bottom from which the wood tar trickles into the collection can as illustrate in Fig. 1. Open heating method was used to supply heat to the metal container for 2 hours, after which the collection can was retrieved together with the wood tar, and the process was repeated for the other batches.

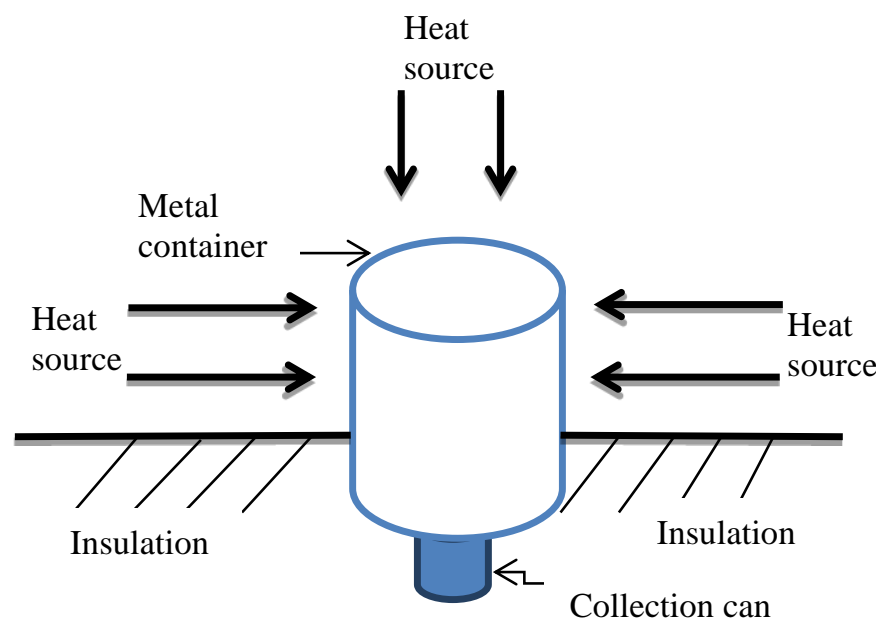

Fig. 1. Schematic of the tar kiln for open fire method.

\section{B. Chemical Analysis}

Gas chromatography (GC) and mass spectrometry (MS) techniques were employed to analyze the wood tar collected.

\section{Soap production: Cold Process Method}

The oil (peanut and castor oil) and wood tar samples were first collected and blended at the required ratio of $1 \%$ to $90 \%$ with a basis of $100 \mathrm{ml}$ measured and transferred into a round bottom flask. The blended oil was then weighed using weighing balance. It was then heated to a temperature of $50{ }^{\circ} \mathrm{C}$ in order to quicken the saponification reaction between the alkali and the oils.

A calculated amount of sodium hydroxide $(12.42 \mathrm{~g}$ ) was weighed and dissolved in distilled water $(28.98 \mathrm{~g})$ to prepare lye solution which was then poured gently to the heated oil and wood tar blend and stirred gently in one direction to enhance thorough mixing of the solution. The soap was then poured into a soap mold and allowed to cool for 24 hours. The soap produced was then weighed. The soap produced was analysed to assess its quality, the process was repeated for all selected oil-wood tar ratios.

\section{Yield}

For all the soap samples prepared the respective masses were taken after they are hardened, and the soap yield was calculated.

\section{E. Foamability}

For each soap sample formulation, $1 \mathrm{~g}$ of the soap sample was dissolved into a $50 \mathrm{ml}$ of water in a $1000 \mathrm{ml}$ measuring cylinder and stirred vigorously for 2 minutes. The height of 
the foam was monitored and recorded after 2 minutes. The procedure was also repeated for the two commercial soap samples considered.

\section{F. Cleansing Power}

To determine the cleaning property of the synthesized soap samples, a drop of oil was placed on a strip of filter paper. The filter paper with the oil spot was immersed in a test tube containing prepared soap solution of the synthesized soap. The soap solution was prepared by dissolving $1 \mathrm{~g}$ of soap in $10 \mathrm{ml}$ of water. It was stirred vigorously for 1 minute after which the filter paper was removed and rinsed with distilled water and the degree of cleanliness of filter paper was observed. This procedure was repeated for all the soap samples produced as well as the commercial soap samples for comparison.

\section{G. $p H$}

For each soap sample, $1 \mathrm{~g}$ of the soap was dissolved in $10 \mathrm{ml}$ of distilled water and the $\mathrm{pH}$ of the solution was determined using a $\mathrm{pH}$ meter. This procedure was also repeated for the commercial soap samples.

\section{H. Microbial Sensitivity Analysis}

Lysogeny broth (LB) was prepared, a loop full of $E$. coli inoculum bacteria was added to the $\mathrm{LB}$ and then poured onto petri plate. A soap solution was prepared by dissolving $1 \mathrm{~g}$ of the soap sample in $10 \mathrm{ml}$ distilled water. At random, a drop of the soap solution was placed using an injection needle on the petri plate. The petri plate was then incubated for 48 hours at a temperature of $37{ }^{\circ} \mathrm{C}$ and the bacterial growth was observed.

\section{Turbidity Test}

LB was prepared and $35 \mathrm{ml}$ was poured into bottle of $5 \mathrm{ml}$ each for seven samples, a loop full of $E$. coli bacteria was added to the LB each and incubated for 24 hours. For each of the various soap formulations, i.e., $1 \%, 10 \%, 20 \%$ wood tar with castor oil and 1\%, 10\%, 20\% wood tar with peanut oil. $1 \mathrm{~g}$ of the soap sample was separately dissolved in $10 \mathrm{ml}$ distilled water and $3 \mathrm{ml}$ each of the dissolved soap solution was added to the six bottles of LB respectively, while one was left as blank. The samples were incubated for another 24 hours, and then each sample was diluted with $10 \mathrm{ml}$ distilled water and the turbidity readings were recorded using the Turbidity meter.

\section{RESUlTS AND DisCUSSION}

\section{A. Wood Tar and Residual Charcoal Yield}

Two primary products were derived from the destructive distillation of the wood samples from all the trees selected, namely: cassia tree, eucalyptus tree and neem tree. The products are wood tar and recovered charcoal.

Fig. 2 shows the amount of wood tar extracted in relation to the amount of wood sample used. It could be seen that neem tree yields the most amount of wood tar per unit mass of wood compared to both cassia and eucalyptus trees. The neem tree wood produced roughly $10 \%$ and $15 \%$ more wood tar compared to eucalyptus tree and cassia tree respectively at all level of wood stock investigated. The amount of wood tar extracted increases monotonically with mass of wood for all the selected trees. The average wood tar extract from neem wood, eucalyptus wood and cassia wood were $38 \mathrm{ml} / \mathrm{kg}$, $35 \mathrm{ml} / \mathrm{kg}$ and $33 \mathrm{ml} / \mathrm{kg}$ respectively. It is therefore more viable to extract wood tar from neem tree than cassia or eucalyptus trees.

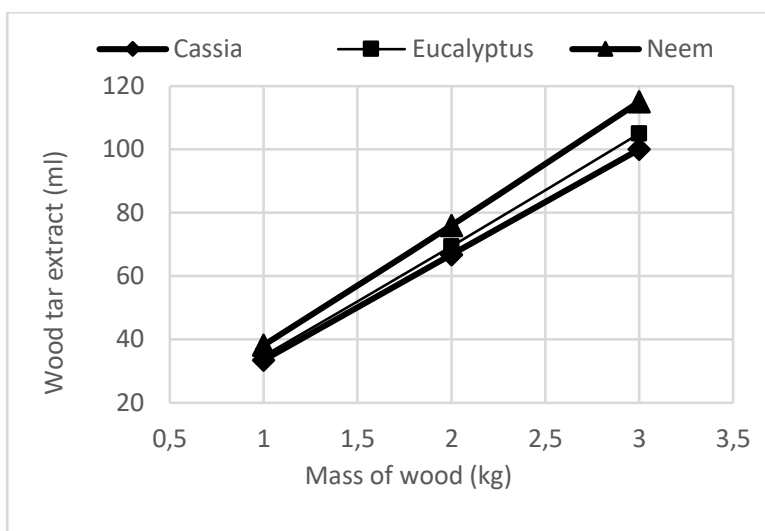

Fig. 2. Amount of wood tar extract from wood of selected trees.

TABLE I: RECOVERED AMOUNT OF CHARCOAL FROM WOOD SAMPLES

\begin{tabular}{cccc}
\hline \hline Mass of Wood & \multicolumn{3}{c}{ Mass of Charcoal $(\mathrm{g})$} \\
\cline { 2 - 4 }$(\mathrm{kg})$ & Cassia & Eucalyptus & Neem \\
\hline 1.0 & 25.52 & 28.35 & 24.10 \\
2.0 & 51 & 56.5 & 48 \\
3.0 & 76 & 85 & 72 \\
1.0 & 25.52 & 28.35 & 24.10 \\
\hline \hline
\end{tabular}

The amount of charcoal recovered after complete destructive distillation of the wood samples is shown in Table 1. Neem tree gives least mass of charcoal compared to eucalyptus and cassia trees. The average mass of charcoal recovered were $24.0 \mathrm{~g} / \mathrm{kg}, 25.0 \mathrm{~g} / \mathrm{kg}$ and $28.0 \mathrm{~g} / \mathrm{kg}$ for neem wood, cassia wood and eucalyptus wood respectively. The neem wood yielded least amount of recovered charcoal due to more wood tar extracted from the neem compared to other trees. The wood tar from neem tree was employed to synthesized soap in this work.

\section{B. Characterization of the Wood Tar}

The wood tar from neem tree was characterized using the GC analysis. Fig. 3 shows the spectral peak of the compounds identified from the GC analysis. In addition, the various compounds present in the wood tar with their molecular formula and percent concentrations were verified from the MS analysis [11]. The presence of compounds such as creosols indicate the antibacterial potential of neem wood tar, thereby making wood tar from neem a viable feedstock for antiseptic soap production.

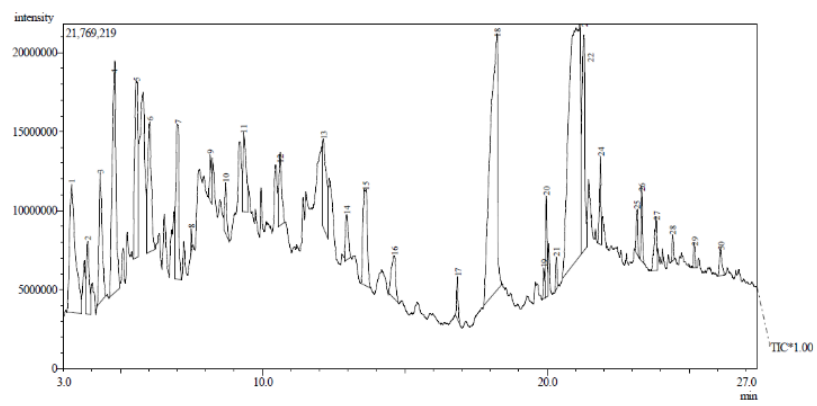

Fig. 3. GCMS analysis of the wood tar extract from neem wood sample. 


\section{Soap Synthesis}

Using the two selected vegetable oils namely peanut oil and castor oil used in this work; varying proportions of wood tar with oil that ensure fair representation were selected and blended to synthesize soap. Tables 2 and 3 show the various selected mass ratios of oil/wood tar blends for both peanut oil and castor oil respectively. The corresponding masses of the soap produced for the various mass ratios of oil: wood tar blends are also presented.

\begin{tabular}{ccc}
\multicolumn{2}{c}{ TABLE 2: MASS OF SOAP PRODUCED FROM BLEND OF CASTOR OIL } \\
\hline \hline $\begin{array}{c}\text { Amount of wood tar } \\
(\%)\end{array}$ & $\begin{array}{c}\text { Mass of castor } \\
\text { oil/wood tar blend }(\mathrm{g})\end{array}$ & Mass soap $(\mathrm{g})$ \\
\hline 1 & 84 & 104.66 \\
2 & 90 & 116.45 \\
3 & 91 & 121.32 \\
5 & 92 & 127.71 \\
10 & 95 & 132.29 \\
15 & 98 & 142.16 \\
20 & 100 & 144.32 \\
40 & 105 & 140.00 \\
\hline
\end{tabular}

TABLE 3: MASS OF SOAP PRODUCED FROM BLEND OF PEANUT OIL

\begin{tabular}{ccc}
\hline \hline $\begin{array}{c}\text { Amount of wood tar } \\
(\%)\end{array}$ & $\begin{array}{c}\text { Mass of peanut } \\
\text { oil/wood tar blend }(\mathrm{g})\end{array}$ & Mass soap $(\mathrm{g})$ \\
\hline 1 & 90 & 115.54 \\
2 & 91 & 123.32 \\
3 & 92 & 125.53 \\
5 & 93 & 127.71 \\
10 & 95 & 131.33 \\
15 & 97 & 142.62 \\
20 & 98 & 143.58 \\
40 & 99 & 139.22 \\
\hline \hline
\end{tabular}

\section{Soap Yield}

Fig. 4 shows the influence of wood tar on soap yield from blends of castor oil and peanut oil respectively. The results indicate that yield increases fairly significantly with increase in amount of wood tar in the blend for both oils. The increase in yield however pass through a maximum at about $15 \%$ wood tar, after which yield decreases with increase in the amount of wood tar in the blend for both oils investigated. Generally, the wood tar-peanut oil blend yields more soap per unit mass of the oil blend than wood tar-castor oil blend. Therefore, peanut oil seems a better choice for soap production with wood tar than castor oil; this is likely due to its lower viscosity that allows the faster saponification process.

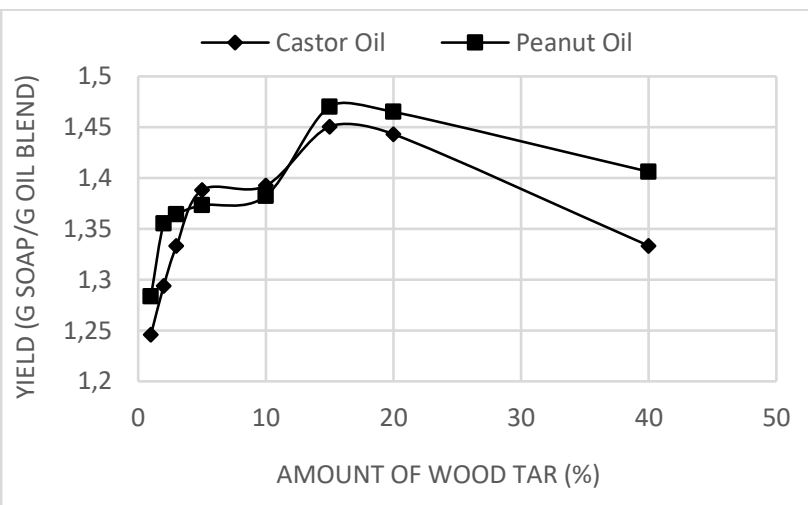

Fig. 4. Soap yield from blend of castor oil and peanut oil with wood tar.

\section{E. Characterization of the Synthesized Soap}

Characterization of the soap samples produced was conducted to evaluate the effect of the amount of wood tar used on quality of the various soap formulations, and also to draw comparison with standard commercial antibacterial soaps.

Typical properties of the representative samples of the standard commercial antibacterial soap are illustrated in Table 4 . The standard soap samples exhibit high foamability of over $300 \mathrm{ml}$ after two (2) minutes of lathering, have very high cleansing power adjudged excellent. The texture is classified as hard, while the $\mathrm{pH}$ of the solution of the commercial soap samples range above 9.0.

TABLE 4: PROPERTIES OF SOME SELECTED COMMERCIAL SOAP SAMPLES

\begin{tabular}{ccccc}
\hline $\begin{array}{c}\text { Soap } \\
\text { sample }\end{array}$ & $\begin{array}{c}\text { Foamability after } \\
\text { 2 minutes }(\mathrm{ml})\end{array}$ & Hardness & $\begin{array}{c}\text { Cleansing } \\
\text { power }\end{array}$ & $\mathrm{pH}$ \\
\hline Sample A & 310 & Hard & Excellent & 9.20 \\
Sample B & 330 & Hard & Excellent & 9.67 \\
\hline \hline
\end{tabular}

Table 5 shows the properties of the synthesized soap samples using blend of both peanut oil and castor oil with wood tar respectively. For both oils, the texture of formulated soap samples is strongly affected by the amount of wood tar in the blend. The lower the amount of wood tar the softer is the synthesized soap for both oil blends formulations. For all wood tar levels above 5\% the soap formulations were adjudged soft for both oil blends. At wood tar levels higher than $40 \%$, both oils could not saponify and hence unable to produce soap.

TABLE 5: PROPERTIES OF SYNTHESIZED SOAP SAMPLES

\begin{tabular}{ccccc}
\hline \hline Soap & \multicolumn{2}{c}{ Soap of castor oil blend } & \multicolumn{2}{c}{ Soap of peanut oil blend } \\
\cline { 2 - 5 } sample & Hardness & $\begin{array}{c}\text { Cleansing } \\
\text { power }\end{array}$ & Hardness & $\begin{array}{c}\text { Cleansing } \\
\text { power }\end{array}$ \\
\hline 1 & Hard & Excellent & Hard & Excellent \\
2 & Hard & Excellent & Hard & Excellent \\
3 & Hard & Very good & Hard & Very good \\
5 & Soft & Good & Soft & Good \\
10 & Soft & Good & Soft & Good \\
15 & Soft & Good & Soft & Good \\
20 & Soft & Fair & Soft & Fair \\
40 & Soft & Poor & Soft & Poor \\
60 & Not & - & Not & - \\
& saponified & - & saponified & \\
80 & Not & - & Not & - \\
\hline \hline
\end{tabular}

The cleansing power of the soap formulations were also affected by the amount of wood tar in the blend. High amount of wood tar adversely affects the cleansing ability of the soap sample for both oil blends.

Fig. 5 shows the influence of the amount of wood tar on the foamability of the synthesized soap samples for both peanut oil and castor oil blends. It could be seen that soaps of peanut oil blends form stable lather for all level of wood tar investigated. However, the foamability decreases slightly with increase in the amount of wood tar. Up to $3 \%$ wood tar, the foamability of the soap samples synthesized from wood tar-peanut oil blends compared favorably well with that of the standard commercial soap samples used (see Table 4 and Fig. 5). 


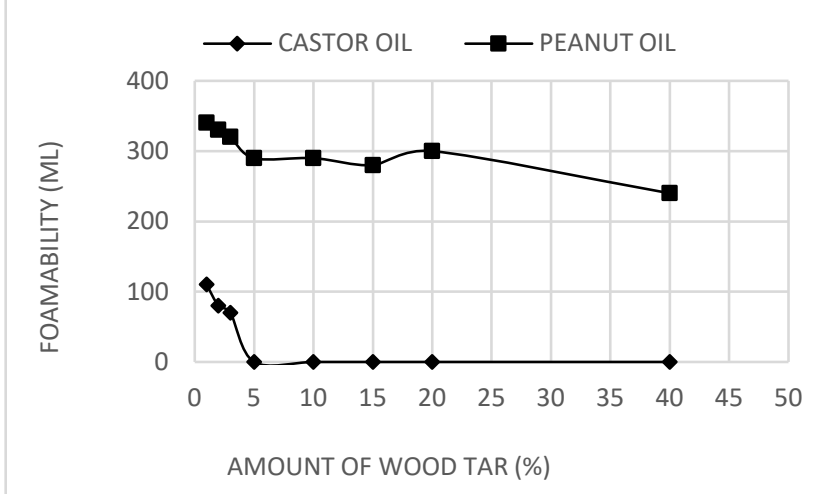

Fig. 5. Effects of amount of wood tar on the foamability of the synthesized soap.

On the other hand, the synthesized soap samples from wood tar-castor oil blends exhibits poor foamability compared to the standard commercial soap samples. Even at $1 \%$ wood tar, the soap sample generates abysmal foamability of only about $35 \%$ that of the commercial soap samples. More also, the foamability of the soap samples decreases significantly with increase in the amount of wood tar. For all levels of wood tar higher than $5 \%$, the soap samples do not form stable lather completely as illustrated in Fig. 5. It is therefore pertinent to note that peanut oil is a better potential feedstock for antibacterial soap production with wood tar based on the foamability of the soap produced. This point is buttressed as illustrated in Fig. 6, which shows the average formability of the standard commercial antibacterial soap samples compared to the formability of the synthesized soap samples from blends of castor oil and peanut oil with $2 \%$ wood tar respectively.

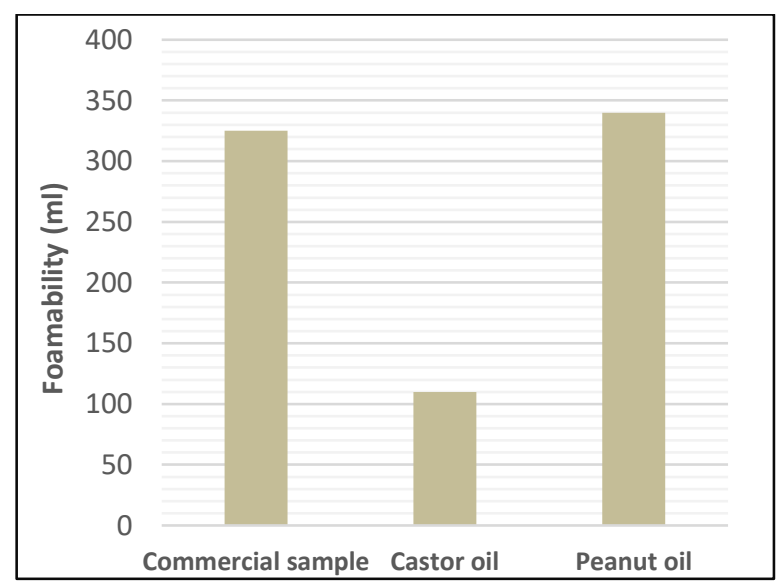

Fig. 6. Foamability of the soap formulations of blends of both oils with $2 \%$ wood tar compared with the average foamability of the commercial soap sample.

The $\mathrm{pH}$ of the various soap samples produced were also determined as presented in Fig. 7. The synthesized soaps solutions exhibit the characteristics basic nature typical of standard antibacterial soaps with $\mathrm{pH}$ range slightly higher than 9.0 for all level of wood tar for both oils. Furthermore, the $\mathrm{pH}$ value of the castor oil and peanut oil soap samples analyzed agree within the acceptable range as reported by [12] and compared favorably with that of the commercial soap samples (Table 4). For a soap not to be lye heavy, the $\mathrm{pH}$ of the soap must range from 9.0 to 11.0.

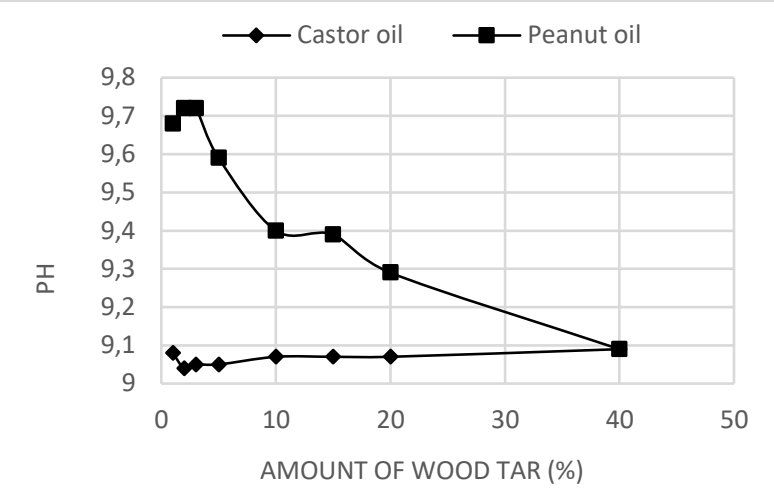

Fig. 7. Effects of amount of wood tar on the $\mathrm{pH}$ of the synthesized soap.

\section{F. Antimicrobial Analysis of the Synthesized Soap}

Fig. 8 (a) shows the addition of $E$. coli bacteria with addition of wood tar soap sample, (b) and (c) shows the sensitive area around the point where wood tar is added. The red spots on the petri plate indicate the sensitive areas where the $E$. coli bacteria growth was hindered due to the antiseptic properties of the wood tar. The sensitivity test therefore confirmed that the soap contains compounds required that could inhibit bacterial growth.

Turbidity values indicate that the wood tar has inhibitory properties by reducing the growth rate of the E. coli bacteria. $1 \%$ and $10 \%$ show a little growth of the bacteria while $20 \%$ shows a total stagnation of the growth rate of the E. coli bacteria. A blank sample shows the increase in the turbidity readings due to lack of addition of any inhibitory properties. Therefore, turbidity test provides a confirmation of antiseptic properties in the wood tar.

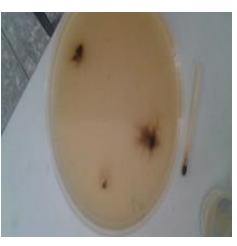

(a)

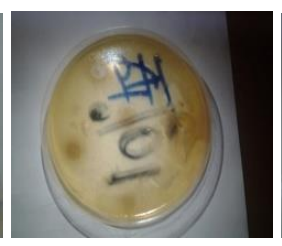

(b)

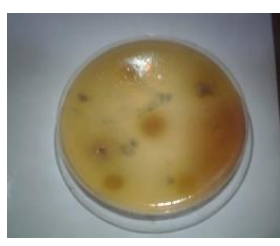

(c)
Fig. 8. (a) E. coli with added wood tar (b) E. coli culture with $10 \%$ wood $\operatorname{tar}(\mathrm{c})$ E. coli culture with $20 \%$ wood tar.

TABLE 6: TURBIDITY TEST OF SYNTHESIZED SOAP SAMPLES ON E. COLI

\begin{tabular}{ccccc}
\hline \hline \multirow{2}{*}{$\begin{array}{c}\text { Amount } \\
\text { of wood } \\
\operatorname{tar}(\%)\end{array}$} & \multicolumn{4}{c}{ Turbidity Values } \\
\cline { 2 - 5 } & \multicolumn{2}{c}{ Castor Oil Blend Soap } & \multicolumn{2}{c}{ Peanut Oil Blend Soap } \\
\hline 0.0 & 1235 & $2 \mathrm{~h}$ & $1 \mathrm{~h}$ & $2 \mathrm{~h}$ \\
1.0 & 1729 & 1767 & - & - \\
10.0 & 1802 & 1808 & 924 & 931 \\
20.0 & 1897 & 1897 & 1234 & 1236 \\
\hline \hline
\end{tabular}

\section{CONCLUSION}

Wood tar was successfully extracted by the open fire burning method; the wood tar was analyzed using GCMS and found to contain the required antiseptic components suitable for the production of antibacterial soap. Two vegetable oils castor and peanut oil; were separately blended with various proportions of wood tar and used to produce soap using cold process method. The different formulations of the synthesized soap were characterized to determine properties such as foam ability, cleansing power and $\mathrm{pH}$. Comparison 
was made with two representative commercial antiseptic soap samples. Peanut oil blended with wood tar was found to yield more soap than castor oil blended with wood tar. More also, soap formulations of peanut oil were found to exhibit properties that compare more favorably to that of the commercial grades. The soap has a $\mathrm{pH}$ of 9.29 , foam ability of more than $300 \mathrm{ml}$ after two (2) minutes and cleaning power adjudged excellent, antibacterial sensitivity test reveals the soap to be active against $E$. coli. Turbidity test also confirms inhibitory property on addition of the synthesized soap against $E$. coli bacteria.

\section{REFERENCES}

[1] S. M. Cavitch, The Natural Soap Book: Making Herbal and VegetableBased Soaps, Storey Publishing, LLC, 1995.

[2] L. Chalmers and P. Bathe, Chemical Specialties, Domestic and Industrial, 2nd ed. Godwin, 1978.

[3] M. Debesh, "Preparation of Soap Using Different Types of Oils and Exploring its Properties," B.Tech. thesis, Dept. of Chemical Eng., National Institute of Tech., Rourkela, India, 2013.

[4] X. Liu, Q. Jin, Y. Liu, J. Huang, X. Wang, W. Mao and S. H. Wang, "Changes in Volatile Compounds of Peanut Oil during the Roasting Process for Production of Aromatic Roasted Peanut Oil," Journal of Food Science, vol. 76, no. 3, pp. C404-C412, March, 2011. Doi: 10.1111/j.1750-3841.2011.02073.x.

[5] Many Authors. (2019). Wood Tar. Available: https://www.britannica.com/science/wood-tar.

[6] D. L. Rockwood, A.W. Rudie, S.A Ralph, J. Y. Zhu and J. E. Winandy, "Energy product options for Eucalyptus species grown as short rotation woody crops,” Int. J. Mol. Sci., vol. 9, pp. 1361-1378, 2008.

[7] M. S. Fradin and J. F. Day, "Comparative Efficacy of Insect Repellents Against Mosquito Bites,” N Engl. J. Med., vol. 347, no. 1, pp. 13-18, July 2002.

[8] V. B. Dash, Materia Medica of Ayurveda Based on Madanapala's Nighantu. $1^{\text {st }}$ ed. New Delhi, India: B. Jain Publishers Ltd., 2001, pp. 41-43.

[9] A. A. Maje, M. Mbattude and S. Nyakaana, "The Uses of Azadirachta Indica A. Juss (Neem Tree) In Taura Local Government Area, Jigawa State, Nigeria" Int. J. Research, vol. 6, no. 9, pp. 155-164, August 2019.

[10] D. P. Agrawal. (2001). Medicinal properties of Neem: New Findings. Available: https://www.infinityfoundation.com/mandala/t_es/t_es_agraw_neem. htm.

[11] R.A. Hites, "Development of Gas Chromatographic Mass Spectrometry,". Analytical Chemistry, vol. 88. No. 14, pp. 6955-6961, 2016.

[12] O. P. Vivian, O. Nathan, A. Osano, L. Mesopirr and W. N. Omwoyo, "Assessment of the Physicochemical Properties of Selected Commercial Soaps Manufactured and Sold in Kenya," Open J. of Appl. Sci., vol. 4, pp. 433-440, July 2014. 